\title{
7.2 Стратегія психотерапії комплексного ПТСР
}

\section{Резюме}

Розглядається стратегія психотерапевтичної допомоги при ПТСР, яке відповідає новим діагностичним критеріям МКБ-11 «Комплексний посттравматичний стресовий розлад», найчастіме спостерігається $y$ ветеранів бойових дій. Психотерапевтичний підхід до лікування изього розладу вимагає синтезу психодинамічних $i$ когнітивно-поведінкових методик, запропонованих у світовій психотерапевтичній практиці. Крім обов'язкового індивідуального підходу, потрібно враховувати етнічні відмінності пацієнтів ветеранів бойових дій в Україні від інших етнічних $і$ сочіокультурних груп хворих.

Ключові слова: комплексне ПТСР, комбатанти, методики психотерапї̈, стратегія лікування.

У проекті МКБ-11 введена нова діагностична категорія «Комплексний посттравматичний стресовий розлад». Це розлад, який виникає після впливу надзвичайного або тривалого за своєю природою стресора, від впливу якого позбутися важко або неможливо. Розлад характеризується основними (стрижневими) симптомами посттравматичного стресового розладу (ПТСР), а також (на додаток до них) розвитком персистуючих, наскрізних порушень афективної сфери, відношення до самого себе і в соціальному функціонуванні, включаючи:

- $\quad$ труднощі в регуляції емоцій,

- $\quad$ відчуття себе як приниженою, переможеною і нікчемною людиною,

- $\quad$ труднощі в підтримці взаємовідносин.

Комплексне ПТСР - це діагностична категорія, яка за задумом укладачів замінює категорію МКБ-10 F62.0 «Стійке зміна особистості після переживання катастрофи». Симптоматика комплексного ПТСР може виникнути після впливу єдиного травматичного стресора, але частіше виникає внаслідок важкого пролонгованого стресу або множинних або повторюваних небажаних подіяй, 
уникнути вплив яких не представляється можливим. ПТСР є станом психічного нездоров'я, яке запускається внаслідок впливу травматичної події. Більше 90\% дорослих, принаймні, один раз в житті стикалися 3 травматичними подіями (наприклад, напад, стихійне лихо, дорожньо-транспортна пригода, військові дії, втрата близьких), а у 8\% - 25\% з них розвивається ПТСР.

Прояви ПТСР мають сильний вплив на психічні функції пацієнтів і безсумнівно потребують лікування. У лікуванні ПТСР істотне місце займають як психофармакотерапія, так i психотерапевтичні методи на всіх етапах реабілітації. Основна мета роботи з пацієнтами полягає в тому, щоб повернути їх на той рівень функціонування, який був у них до травми. Однак це часто нереалістичне завдання. Психічна травма участі в бойових діях руйнує імпліцитну картину світу комбатанту i вимагає додаткових особистісних ресурсів. Завдання психотерапії полягає в тому, щоб допомогти пацієнтові встати на шлях адаптивного розрішення множинних травмуючих ситуацій.

Виділяють чотири стратегії терапії, до яких можуть бути зведені фактично всі форми психотерапії ПТСР:

1) Підтримка адаптивних навичок «самості» - «Я». Особистості. Існує безліч Я-підтримуючих аспектів терапії ПТСР. Одним з найбільш важливих є позитивні терапевтичні взаємовідносини. Необхідно забезпечити розвиток терапевтичного альянсу, особливо якщо пацієнту доведеться зіткнутися 3 болісними спогадами i переживаннями. Розумне пояснення майбутніх терапевтичних втручань дає пацієнтам відчуття контролю над ситуацією, необхідне для підтримки нормального функціонування.

Horowitz [358] вивів загальні принципи використання психотерапевтичних втручань. Мета психотерапії при ПТСР полягає в тому, щоб утримати пацієнта в оптимальних межах між симптомами надмірного відкидання i надмірної нав'язливості. Дані втручання можуть використовуватися для багатьох цілей. Існує також ряд специфічних терапевтичних втручань, які використовуються тільки для підтримки, наприклад, зменшення зовнішніх вимог і відпочинок, тренінг релаксації, систематична десенсибілізація, образи, розмови з самим 
собою, гіпнотичне відновлення ресурсів, гіпнотичні Я-підтримуючи навіювання і медикаментозне лікування.

2) Формування позитивного ставлення до симптомів. Особи, які страждають ПТСР, за визначенням, пережили подію, що виходить за рамки нормального людського досвіду. Вони відчувають реакції, які їм незрозумілі і надзвичайні для нормальної життєдіяльності. Багато терапевтичних систем явно чи неявно допомагають пацієнтам визнати, що їх реакції, враховуючи екстремальні обставини, є нормальними. Ці стратегії мають дві основні цілі:

По-перше, запобігання подальшої травматизації пацієнтів цими симптомами (інакше кажучи, допомога в пригніченні негативного циклу розвитку відхилення).

По-друге, створюють для пацієнтів таку атмосферу, при якій вони мають можливість використовувати свої власні ресурси (які інакше б не використовувалися).

Терапевтичні втручання, зосереджені на формуванні позитивного відношення до симптомів, як правило, використовують як аспекти Япідтримуючих втручань, так і аспекти терапевтичних втручань для зміни атрибуції сенсу. Використовуються такі елементи психотерапії, як зменшення уникнення. Практично всі обговорювані терапевтичні підходи засновані на зменшенні уникнення, як головної стратегії лікування. Уникнення може відбуватися на декількох рівнях:

1. уникнення афектів або почуттів (оціпеніння);

2. уникнення спогадів про травматичну подію (амнезія);

3. поведінкові уникнення (фобічні реакції);

4. уникнення обговорення події.

Тенденція до уникнення зіткнення з травмою і всього, що з нею пов'язано, повинна бути нейтралізована 3 двох причин: по-перше, пацієнти не можуть переробити травматичний досвід самі, в зв'язку з тим, що вони уникають все, що пов'язане з ним, і тому цей досвід продовжує залишатися болісним. По-друге, уникнення саме по собі стає проблемою, яка в подальшому загострює ситуацію. 
Наприклад, уникнення може стати більш генералізованим, воно може привести до порушення спілкування з членами родини тощо.

Зміна атрибуції сенсу. Оскільки атрибуція сенсу травматичної ситуації і реакцій пацієнта на неї є складовою частиною розладу, не дивно, що одна 3 терапевтичних стратегій повинна змінити сенс, який надається травматичній ситуації і їі наслідкам. Для деяких моделей (тренінг стійкості до стресу, сімейна терапія, гіпноз, психодинамічна терапія) існують прямі терапевтичні втручання, які сприяють зміні сенсу, який придає пацієнт травматичному переживанню. Деякі з цих втручань включають в себе інтерпретацію, створення подібної ситуації, розвиток теорії зцілення, когнітивне переструктурування, переміщення уваги з минулого на майбутне [359].

Імпліцитні вказівки до зміни атрибуції існують у всіх терапевтичних школах. Центральними темами $є$ наступні: можливість пацієнта винести болючі спогади і емоції; розвиток самоефектівності; зміна образу себе.

Frederick [360] визначив ще одну атрибутивну зміну, як обов'язкову умову ефективного вирішення ПТСР - виробити відчуття «контролю над травмою». Можна охарактеризувати таке відчуття, як загальну кінцеву мету, до якої прагнуть всі терапевтичні втручання.

Одним 3 найбільш впливових і евристичних підходів до пояснення та лікування ПТСР є концепція, яка розробляється М.Horowitz'ем [358,361,362]. Хоча багато авторів виступають проти психоаналітично орієнтованої терапії ПТСР, Horowitz захищає динамічний підхід до лікування цього розладу. Відмінність його концепції від традиційного психоаналізу полягає в синтезі 3 теорією переробки інформації і когнітивним підходом до емоцій.

Іншою важливою особливістю підходу Horowitz'a $€$ те, що, на відміну від більшості досліджень терапії ПТСР він не зосереджений виключно на ветеранах війни. Його увага сфокусована на жертвах злочинів (наприклад, насильства, нападів, грабежів тощо), жертви нещасних випадків, на людях, які втратили близьких тощо. Цей підхід може широко застосовуватися до різноманітних груп 
пацієнтів з ПТСР. Крім того, підхід Horowitz'a $є$ концептуальною моделлю, в рамках якої можна розглянути інші стратегії лікування та їх застосування.

Грунтуючись на класичних і сучасних психоаналітичних теоріях травми, Horowitz приділяє основну увагу інформаційному перевантаженню і неповної обробки інформації ( «інформація» включає ідеї з внутрішніх і зовнішніх джерел, образи і афекти). Травматичний досвід є занадто значним, щоб бути одразу переробленим, тому він відкладається зі свідомості, де він зберігається в «активній формі пам'яті». Відкидання - оціпеніння захищають «Я» від травматичної інформації. Зазвичай відбуваються вторгнення (тобто ідеї, образи, «емоційні атаки», компульсивна поведінка, тощо), що викликаються зовнішніми подіями. Коливання між відкиданням - оціпенінням і вторгненнями триває до моменту, поки інформація не буде повністю перероблена. Це природний аспект переробки інформації. Увага зосереджена скоріше на виконанні переробки інформації, ніж на відреагуванні і катарсисі. Horowitz розглядає вторгнення, як потенційне полегшення переробки інформації та захисні дії, як просування поступової асиміляції травматичного досвіду. Існують також неадекватні аспекти (вторгнення можуть пригнічувати пацієнта, а захисні маневри можуть перешкоджати переробці).

Дотримуючись вищезазначеного, Horowitz виділяє прогресивні стадії в реакції на потужний стрес:

1. Стадія I: потужний стрес - реакції плачу і приголомшення;

2. Стадія II: уникнення (відкидання і оціпеніння);

3. Стадія III: період вагання (відкидання і оціпеніння - вторгнення);

4. Стадія IV: перехід ( «переробка»);

5. Стадія V: інтеграція ( «завершення переробки інформації»).

Horowitz підкреслює, що переробка і інтеграція травматичного досвіду дуже складний процес.

Центральна теза підходу Horowitz'a до лікування стресових розладів необхідність переробки інформації (скоріше, ніж зміна характеру), при цьому основна увага спрямована на явища вторгнення і відкидання - оціпеніння. 
Вагання між відкиданням - оціпенінням і вторгненнями як аспектами реакцій на стрес дають основу загальної стратегії лікування. Увага Horowitz'a зосереджується на характерних стилях (тобто, нав'язливому і істеричному) переробки інформації, що забезпечує специфічність терапевтичних підходів до різних типів пацієнтів.

Розгляд складнощів пацієнта в термінах надконтролю (тобто, сильні тенденції до витіснення, відкидання, оціпеніння тощо) і недостатності контролю (тобто, невдача в функціонуванні психологічного захисту супроводжується вторгненнями) в різних психічних системах вимагає відповідних методів лікування і стосується процесів контролю, переробки інформації та емоційної переробки.

Для пацієнта в стадії відкидання - оціпеніння, Horowitz вважає за необхідне:

- скорочення контролю (наприклад, інтерпретація засобів захисту, гіпноз і наркотичний гіпноз, навіювання, соціальний вплив, психодрама);

- зміна установок, що створюють необхідність контролю;

- $\quad$ розкривають інтерпретації.

Для пацієнтів в стадії повторюваних вторгнень 3 метою зміни процесів контролю необхідно:

- забезпечення зовнішнього контролю;

- $\quad$ присвоєння терапевтом функцій Я (тобто, організація інформації);

- скорочення зовнішніх вимог і стимулів;

- $\quad$ відпочинок і релаксація;

- забезпечення моделями ідентифікації (наприклад, за допомогою членства в групі);

- $\quad$ зміна поведінки.

Метою цих втручань $є$ полегшення переробки інформації, а не збільшення або зменшення контролю.

Щодо пацієнтів в стадії відкидання - оціпеніння Horowitz пропонує: 
- $\quad$ заохочення відреагування;

- $\quad$ заохочення асоціації, мови, використання образів (а не точних слів) в спогадах і фантазіях, введення в дію (наприклад, програвання ролей, психодрама, арт-терапія);

- $\quad$ використання реконструкцій.

Для пацієнта в стадії повторюваних вторгнень підходять наступні втручання:

- $\quad$ переробка і реорганізація (наприклад, за допомогою роз'яснення, виховально - інтерпретаційна робота тощо);

- зміцнюючи контрастуючи думки;

- усунення стимулів навколишнього середовища;

- $\quad$ використання медикаментів для пригнічення роздумів.

Як і раніше, метою є продовження переробки травматичної інформації.

Для зміни емоційної переробки у пацієнтів в стадії відкидання - оціпеніння застосовують: (1) катарсис, щоб протидіяти нечуйності і (2) побудова взаємовідносин (з акцентом на емоційній участі).

Для пацієнтів в стадії повторювальних вторгнень застосовується: (1) підтримка; (2) викликання контрастуючих емоцій; (3) використання медикаментів для пригнічення переповнючих емоцій; (4) процедури десенсибілізації; (5) релаксація і біологічний зворотний зв'язок (biofeedback).

Horowitz зазначає, що прогресивне проходження пацієнта через різні стадії змінює пріоритети і цілі терапії, що, в свою чергу, викликає зміни в методах.

Пріоритет I. Коли пацієнт переживає зовнішню стресову подію, цілі лікування полягають в: (1) захисті пацієнта; (2) видаленні пацієнта від впливаючої події; (3) усунення зовнішньої події. По суті, вплив стресора вже скорочено або усунуто. У ситуаціях війни це може полягати в поверненні пацієнта 3 театру військових дій. Як би там не було, в більшості випадків стресогенна подія буде закінчена до лікування.

Пріоритет II. Якщо пацієнт відчуває коливання від відкидання - оціпеніння до повторюваних вторгненнь на занадто високому рівні, потрібно: (1) 
спробувати скоротити амплітуду коливання до толерантного рівня;

підтримати пацієнта емоційно та інтелектуально; (3) підібрати і застосувати відповідні методи.

Пріоритет III. Якщо пацієнт «застряг» в стадії відкидання - заціпеніння або в стадії повторюваних вторгнень, терапевт повинен допомагати в точному «дозуванні» переживання, тобто допомагати пацієнтові розділити переживання на відповідні маленькі і тому потенційно інтегровані інформаційні одиниці. Для цього використовуються відповідні техніки, з перерахованих вище.

Пріоритет IV. Коли пацієнт здатний винести епізоди повторюваних вторгнень, його метою стає «переробка». На це направлено залучення травматичного стресора в докладний умоглядний і емоційний аналіз, а також в об'єктні відносини і образ себе.

Пріоритет V. Початком завершення переробки інформації можна вважати появу у пацієнта здатності до переробки ідей і емоцій, що відносяться до події. Horowitz попереджає, що різні «комплекси» (тобто, різна інформація, пов'язана 3 різними аспектами вихідного стресора) можуть прогресувати незалежно один від одного, виробляючи складну клінічну картину. Терапевт повинен звернути увагу на цю складність. Аналізуючи пацієнтів з істеричним стилем переробки інформації, Horowitz виділяє такі характерні для цих пацієнтів риси: глобальна увага, неясна і неповна представленість ідей і почуттів, часткові і непрямі асоціативні лінії, поведінка, яка привертає увагу, постійно мінливий настрій і емоції, непостійні повторювальні відносини, стереотипні i імпульсивні взаємовідносини і драматичний стиль життя. Horowitz виділяє кілька істеричних когнітивних способів уникнення небажаних думок:

- уникнення уяви;

- уникнення інтермодального перекладу;

- $\quad$ уникнення автоматичних асоціативних зав'язків;

- уникнення свідомих думок про вирішення проблеми;

- $\quad$ зміна ставлення до себе від активного до пасивного (і навпаки); 
- зміна станів свідомості (наприклад, зміна ієрархії бажань і страхів, змішування реальності і фантазії, дисоціація конфліктуючих відносин, уникнення активності в думках і діях тощо).

Щоб допомогти істеричному пацієнтові в переробці інформації травматичної події, Horowitz пропонує терапевтичні тактики для різних стилістичних дефектів, що відносяться до різних психічних функцій (тобто функції перцепції, уяви, мультимодального перекладу, асоціації та вирішення проблем).

Вони включають:

- 'ясування деталей, які демонструє пацієнт, глобальної і вибіркової відсутності уваги (функція перцепції);

- $\quad$ заохочення відреагування і стимулювання реконструкції образів від розпливчастих до більш точних (функція уяви);

- заохочення пацієнта до розмови (i забезпечення вербальними штампами), якщо здатність пацієнта до перекладу образів і дій в слова обмежена;

- $\quad$ заохочення пацієнта до розмови, повторам і додатковим поясненням, в тих випадках, коли пригнічення і неправильні інтерпретації, втручаються в асоціативні функції пацієнта;

- $\quad$ iнтерпретації і напрямок фокуса на тему, де пацієнт швидко і легко приходить до вирішення проблеми;

- $\quad$ забезпечення підтримки, коли уникають теми через переповнюючи емоції (функція вирішення проблеми).

Пацієнтів з нав'язливим стилем переробки інформації об'єднує детальна і гостра увага до подробиць, чітка уява думок, скупа представленість емоцій, зміщення в організації та сплутаності думок (скоріше, ніж дотримання однієї асоціативної лінії), уникнення завершення і прийняття рішень, сумніви $\mathrm{i}$ занепокоєння, продуктивність і / або зволікання, концентрація на одній ідеї, інтелектуалізація, напруженість, ригідність, рутинні міжособистісні взаємовідносини, домінування суперего. Для переробки травматичної інформації в нав'язливому стилі Horowitz пропонує: 
- вимога загальних вражень замість надмірно детального і фактичного сприйняття;

- $\quad$ вимога емоційних переживань;

- $\quad$ зв'язування емоційних і розумових значень замість відокремлення ідей від емоцій (функція уявлення);

- $\quad$ фокусування уваги на образах і чуттєвих реакціях ніж на розумових аспектах інформації (функція вербалізації);

- інтерпретація захисних операцій;

- $\quad$ інтерпретації зволікання через нескінченні роздуми (функція вирішення проблем).

Головне в лікуванні пацієнтів нав'язливого типу - допомогти зосередитися на певній частині інформації так довго, щоб можна було витягти, віднести до якоїсь категорії і інтегрувати іiі емоційний аспект. Така безперервна увага полегшує переробку інформації. Терапевт домагається цього шляхом роботи в більш повільному темпі, ніж у пацієнта, підкреслюючи конкретне, а не абстрактне.

Необхідно відзначити, що крім зазначених вище прийомів і стратегій, які використовуються при лікуванні ПТСР представники самих різних психотерапевтичних шкіл в своїй практичній роботі активно використовують методичні прийоми біхевіоральної терапії.

У літературі обговорюються чотири основних біхевіоральних методи для індивідуального лікування ПТСР:

(1) імплозивна терапія і потік образів;

(2) систематична десенсибілізація;

(3) репетиція поведінки;

(4) тренінг стійкості до стресу.

Кожен 3 цих методів коротко викладено нижче. Найбільш загальною формою біхевіорального лікування, описаного в літературі, є імплозивна терапія або потік образів. Сенс терапії полягає в повторенні подібних уявлень травматичних для пацієнта події до тих пір, доки епізод не перестане викликати 
високий рівень занепокоєння. Метою процедури є скорочення уникнення травматичних спогадів і викликаного ними занепокоєння.

У літературі були описані різні процедури, які використовуються при роботі з пацієнтами з ПТСР. Наприклад, у запропонованій Keane та ін., [363,364] процедурі імплозивної терапії виділяють три стадії:

Стадія I: Тренінг релаксації. Пацієнт з ПТСР навчається прогресивній м'язовій релаксації. Пацієнт спочатку вчиться релаксації через напруження розслаблення 16-ти м'язових груп, потім напруга, як частина процесу знімається. У підсумку, тренінг призводить до того, що ключові слова (наприклад, «важкий, вільний і теплий») викликають реакцію релаксації. Пацієнта заохочують займатися вдома. Тренінг релаксації підвищує можливості пацієнта до уяви епізоду травматичної події і зменшує занепокоєння, яке викликається цією уявою на стадії III. Тренінг релаксації зазвичай проводиться приблизно в чотири сеанси.

Стадія II: Тренінг приємних образів. Після отримання реакції релаксації, пацієнта навчають уяві приємних образів. Цим переслідуються дві мети: приємні образи сприяють релаксації і дозволяють терапевту визначити здібності пацієнта до роботи уяви.

Стадія III: Ця стадія складається 3 ряду фаз: Розвиток ієрархії травматичних спогадів. Пацієнта просять ідентифікувати свої травматичні спогади. Якщо було більше одного травматичного переживання, різні травми повинні бути ієрархічно впорядковані, від менш болючих до більш болючих. Якщо була тільки одна травма 3 безліччю епізодів, тоді повинна бути сконструйована ієрархія епізодів. Оцінка стресових спогадів. Кожен спогад суб'єктивно оцінюється за шкалою від 1 до 10 (1 - що не викликає занепокоєння, 10 - викликає найбільше занепокоєння). При наявності більш одного спогаду, терапія повинна починатися з самого легкого.

Релаксація. Перед поданням травматичних спогадів на сеансах пацієнт повинен розслабитися, використовуючи навички прогресивного м'язового 
розслаблення. Це збільшує можливості уяви пацієнта і усуває думки, не пов'язані із завданням, які стоїть перед ним.

Відтворення епізоду. Як тільки пацієнт розслабився, терапевт використовує ключові стимули (візуальні, слухові, тактильні та нюхові) для відтворення в уяві пацієнта травматичного епізоду. Взаємодія з пацієнтом 3 приводу деталей епізоду створює найбільш реалістичний образ у свідомості пацієнта.

Уява травматичних ключових подразників. Після відтворення епізоду терапевт проводить пацієнта через травматичну подію. Це повинно супроводжуватися підтримкою пацієнта. Постійна взаємодія 3 пацієнтом дозволяє максимально представити деталі події. Особлива увага має бути зосереджена на факторах, що викликають найбільше занепокоєння.

Уява додаткових ключових подразників. Терапевт, повинен допомогти пацієнтові згадати дві категорії додаткових ключових подразників. По-перше, це ключові подразники, що представляють собою небажані думки, почуття або образи пацієнта, які асоціюються 3 травматичною подією. Ці ключові подразники є когнітивною реакцією пацієнта на подію і можуть включати такі почуття, як вина, гнів і засмучення. Другою категорією $є$ гіпотетичні ключові подразники, які включають страхи перед тілесним ушкодженням, смертю, агресивною поведінкою, покаранням за неправильні дії, неприйняттям. Доведено, що гіпотетичні ключові подразники відносяться до основних властивостей, які обумовлюють первинну травму, i тому є причинами багатьох труднощів пацієнтів (наприклад, міжособистісні проблеми.)

Руйнування епізоду. За допомогою процедури потоку образів терапевт добивається зниження суб'єктивної оцінки дистресу, тобто через кілька сеансів знижується занепокоєння, викликане цим епізодом. У ситуаціях з більш ніж одним травматичним спогадом робота 3 наступною в ієрархії травматичною подією починається тільки тоді, коли занепокоєння, яке викликане попередньою в ієрархії подією, знижено. 
Заключний сеанс. В кінці сеансу знову використовується релаксація. Також може слідувати обговорення сеансу. Робота 3 кожним травматичним спогадом триває до того моменту, поки рівень, викликаний їм, занепокоєння не стає дуже низьким.

Систематична десенсибілізація використовувалася при лікуванні різних симптомів, які зазвичай виявляються при ПТСР. Більшість літератури 3 цього питання присвячено специфіці лікування бойового ПТСР. Разом 3 тим, систематична десенсибілізація може бути застосована до всіх груп пацієнтів 3 ПТСР. Репетиція поведінки використовується для лікування серйозних посттравматичних реакцій у жертв автомобільних аварій. Зазвичай план лікування, складається з двох фаз: тренінгу релаксації і репетиції поведінки.

Тренінг стійкості до стресу (ТCC) був розроблений Meichenbaum [365] як інтегральний підхід когнітивно-біхевіоральної терапії. 3 теоретичної точки зору, ТСС зосереджений на розробці правил особистісної відповідальності та активності в протистоянні стресових подій, паралельно зі зменшенням почуття безпорадності i руйнуванням атрибуцій пасивної жертви. Тому ТСС пропонується, як відповідний метод для роботи з ПТСР. ТСС ділиться на три фази: (1) концептуалізація, (2) придбання навичок і репетиція; (3) застосування і підтвердження. У фазі концептуалізації основна увага приділяється навчанню в формі співпраці. Одним 3 факторів, що підсилюють симптоми ПТСР, $є$ неготовність пацієнтів до труднощів, саме тому важливо вселити пацієнтам непридатність реакції повної несприйнятливості до травми. При зборі даних в ТСС особливо важлива реконструкція на основі образів. Клієнтів просять повернутися до травматичної ситуації і уявити іiі. Деталі прихованих образів можуть привести до більш повного розуміння ключових подразників, атрибуцій і ідіосинкратичних переживань, які є важливими аспектами травми. «Образи» повинні бути максимально деталізованими в візуальній, слуховій, кінестетичній і нюховій модальності. Внутрішні установки, атрибуції та оцінки дають важливий матеріал для лікування. У другій фазі ТСС проводиться розрізнення інструментальних і паліативних пристосувальних навичок. Інструментальне 
пристосування - це дії, які служать задоволенню вимог навколишнього середовища або зміни стресових ситуацій i взаємодій, а паліативним пристосуванням є найбільш прийнятне реагування в неминучих стресових ситуаціях, коли інструментальне пристосування неможливо. Цей розподіл особливо важливий, оскільки психотерапевт, а тим більше пацієнт, повинні розуміти, що біль і стрес неминучі. У будь-якому випадку травматична ситуація вже в минулому i iї повторення малоймовірно. У пацієнтів залишаються симптоми, проти яких є всього кілька інструментальних навичок пристосування. Наприклад, для жертв злочинів нерозумно повністю позбутися від спогадів про пережите і від почуття страху. Важливо мати відповідні паліативні навички пристосування для таких випадків. Прикладом паліативного досвіду може служити відновлення впевненості у власних силах і реакції релаксації. Прикладом інструментального пристосувального навику є навчання карате для протистояння можливому в майбутньому насильству. Veronen and Kilpatrick [366] описують використання ТСС з жертвами згвалтування. У першій фазі лікування клієнтам дається розумне пояснення ТСС. Жінкам вселяли, що їх реакції i їх прояви (поведінкові, когнітивні i фізіологічні) нормальні. Обговорювалися також феномени реакції страху. Навички включають м'язову релаксацію, контроль дихання, програвання ролі, приховане моделювання, уявне блокування і контрольований діалог з собою. В кінці кожного сеансу дається домашнє завдання, яке полягає або в практиці пристосувальних механізмів стосовно щоденних стресорів, або у виконанні наближення до обгрунтованого страху (в даному випадку до страху перед згвалтуванням).

Існує безліч труднощів, пов'язаних з лікуванням ПТСР. Ці проблеми стають більш очевидними, якщо травма дуже серйозна, порушення прийняли хронічну форму або при відкладанні лікування. Первинні і вторинні симптоми розладу, які достатньо зміцнилися, можуть представляти суттєві труднощі. Помилки в процесі діагностики, особливо властиві психотерапевту, також ускладнюють лікування. Крім того, в практиці роботи 3 пацієнтами часто відзначають такі проблеми як: -небажання пацієнта спілкуватися 3 
психотерапевтом; -страх, що ніхто не зможе правильно зрозуміти травматичний досвід; -труднощі в міжособистісних відносинах; -почуття образи по відношенню до влади; -потужні реакції перенесення; -зловживання ліками, алкоголем і наркотиками; -інтенсивне психічне оціпеніння; -ослаблення Яконцепції; -глибоке почуття провини і сорому;

Часто відзначають труднощі лікування ветеранів війни, що виникають 3 вини психотерапевта, які також можуть бути загальними для всіх типів ПТСР: сприйняття пацієнтів «лиходіями» або винуватцями травми; -сприйняття пацієнтів «жертвами»; -складності протистояння почуттю власної вразливості; пошук «фатальної вади» у пацієнта (який пояснив би, чому пацієнт став жертвою травми, і якої не було б у психотерапевта). У висновку необхідно відзначити, що проблема психотерапії пацієнтів з ПТСР вимагає свого подальшого вивчення та систематизації. В першу чергу, це пов'язано з проблемою ефективності різних форм психотерапевтичного втручання, а по-друге, 3 культурними i національними особливостями. Багато методик, які успішні на Заході, не «працюють» при наданні психотерапевтичної допомоги комбатантам в Україні.

Майже всі психологи-дослідники виділяють такі характеристики українського національного характеру: демократичність, любов до волі, емоційність, яка проявляється в любові до музики, наближеність українців до природи, культ жінки і сім'ї, релігійність, толерантність до інших народів, працьовитість, гостинність.

Більшість дослідників схиляється до того, що українці за своєю суттю інтроверти, тобто, спрямовані на власний психічний світ, на проблеми перш за все власного соціуму. Саме тому, в українському суспільстві родина, найближча родина мали велику цінність. Важливо зауважити, що, інтровертованість проявляється в миролюбності, несхильності до агресії та насильства, в зосередженні на власній внутрішній свободі. Певна закритість для зовнішнього світу породжує особистісну стриманість, витримку і наполегливість. 
Практично всі дослідники визначають таку характерологічну рису українців, як індивідуалізм, який виражається в неслухняності, в граничних своїх проявах веде до відкидання будь-якої влади, до анархізму.

Тривала відсутність в Україні державності не сприяла формувань у нації відповідальності за власну долю, народжувала політичну пасивність, очікування, що хтось інший зможе вирішити їх проблеми. Якщо такі очікування не виправдовуються, тоді починається пошук винного, але тільки не в собі, в інших.

Недостатній розвиток соціальної волі також визначається багатьма дослідниками українського етносу. Домінування емоційності, фантазій над волею в характері українців часто призводила до того, що поставлені цілі не були досягнуті, або реалізовувалися не так, як були задумані.

Формування цілісного українського національного характеру тільки починається і вимагає багато історичного часу. Дуже важливо враховувати, що жодна з рис характеру сама по собі не визначає його суть взагалі, а відображає лише певний спосіб реагування на обставини, форму переживання зовнішньої дійсності. 